\title{
Expanding Predictive Policing, Enhancing Infiltration Strategies
}

\author{
C. Goerzig
}

\begin{abstract}
Predictive policing seeks to make predictions about criminal activity by using comprehensive collected data as inputs to statistical models. Borrowing from the conceptual tool box of political science, this paper lays out a further possibility for enhancing predictive policing: qualitative research in order to discern conditions that explain success or failure of interventions, specifically infiltration strategies. Whereas predictive policing focuses on individual actors that commit criminal acts, the 'hot spots' identified in this paper are not individual perpetrators but collective movements (organized crime). Additionally, the focus lies on evaluating intervention strategies by identifying efficient infiltration strategies for informants. While predictive policing focuses on "hot spots" and "hot people," the tool developed in this paper focuses on "hot collective movements" (organized crime) and "hot intervention strategies" (infiltration). It develops a conceptual tool to establish effects of and on infiltration, based on enabling or hindering conditions traced in qualitative case comparisons. Expanding variable variety through qualitative case comparisons in order to account for effects of and on infiltration makes predictive policing dynamic and, potentially, more predictive.
\end{abstract}

Index Terms-Infiltration, organized crime, predictive policing, qualitative research.

\section{INTRODUCTION}

Predictive policing seeks to make predictions about criminal activity by using comprehensive collected data as inputs to statistical models: "Predictive Policing is the application of analytical techniques - particularly quantitative techniques - to identify likely targets for police intervention and prevent crime or solve past crimes by making statistical predictions [1]." For example, it seeks to further develop programs such as Crime Mapping, which provides information about crime activity by neighborhood, and COMPSTAT, which makes use of Geographic Information Systems to map crime and identify problems, by expanding data input. Whereas "what happens next equals what just happened" previously implied reference to events from only the previous month, predictive policing allows for taking into account the last three months. Furthermore, the variety of data is increased to account for a multiplicity of factors that may play out in future criminal activity. Too often, improving policing remains surface-level due to a lack of know-how. Referring to Mexico's plan to change its policing,

Manuscript received December 4, 2014; revised January 20, 2015. This research was financially supported by the German Academic Exchange Service.

C. Goerzig is with the Virginia Commonwealth University, Richmond, VA, 23284, USA (e-mail: cgoerzig@vcu.edu).
Daniel Sabet, Visiting Professor at Georgetown University, commented recently, "' $[\mathrm{m}] \mathrm{y}$ main concern is it changes who does policing and not how policing is done [2]." Predictive policing can play a major role in redressing how policing is done. Mapping out a multiplicity of influential factors helps to re-design policy measures to address gaps and channel scarce resources.

Borrowing from the conceptual tool box of political science and terrorism research, this paper lays out a further possibility for enhancing predictive policing: introducing qualitative research in order to discern the conditions that explain success or failure of interventions, specifically infiltration strategies. Although "breaking the law to enforce it [3]" remains contested, arguably "information and intelligence have always been, and will remain, the most essential components of policing and indeed all law enforcement and security work...[4]“ As Gary Marx states "There is of course nothing new about this practice [5]." Whereas undercover policing involves the invasion of privacy and can lead to police corruption, "it is increasingly seen as an efficient and even necessary strategy to combat major crime problems [6]." Focusing on infiltration strategies as a source of information gathering, predictive policing is here expanded not only in terms of the actor identified, but also the strategy employed: The "hot spots" identified in this paper are not individual perpetrators but collective movements (organized crime). Additionally, the focus lies on evaluating an intervention strategy by identifying efficient infiltration strategies for informants. Whereas predictive policing focuses on "hot spots" and "hot people," the tool developed in this paper focuses on "hot collective movements" (organized crime) and "hot intervention strategies" (infiltration). Expanding variable variety through qualitative case comparisons in order to account for effects of and on infiltration makes predictive policing dynamic and, potentially, more predictive.

Thus, qualitative case comparisons shall serve to find conditions crucial for infiltration success. Since "[u]ndercover work is arguably the most problematic form of policing undertaken by municipal police departments, and little is known about it in operation [7]," mapping out conditions for infiltration success is essential. Moreover, the results of this investigative approach can be translated into preemptive policies. Conditions indicate when strategies lead to either one outcome or another, thereby facilitating predictions about success or failure of an intervention or infiltration strategies. Inquiring under which conditions which strategy leads to which outcome can help to channel limited resources into promising strategies to counter crime.

The following sections will develop a conceptual tool to 
discern the effects of, and the effects on, infiltration based on enabling or hindering conditions traced in qualitative case comparisons. It suggests a research design that expands predictive policing and that can be implemented to enhance infiltration strategies. Three sections develop the conceptual approach. The first section expands variable variety in order to enable finding the conditions for infiltration success. The following section makes the tool dynamic by looking at the effects of infiltration on the transformation of criminal groups and the effects of the transformation of criminal groups on infiltration - in short, the feedback loop of infiltration. The last section brings variable variety and infiltration dynamics together, painting a complex picture of how predictive policing can be expanded and infiltration strategies be enhanced.

\section{A. Variable Variety}

Predictive policing broadens the focus on "hot spots" with a complementary focus on "hot people." This paper proposes to additionally consider that criminals are often organized in collective groups, i.e., "hot movements." Social network analysis provides a useful tool to investigate the organizational structure of collective movements as put into practice by intelligence software systems such as Analyst's Notebook or Crime Link. These tools help decision-makers to discern the relationship between organization-related details and to draw link charts of organizational structures. Social network analysis is used "to look beyond the network structure into its dynamics - to identify characteristics of networks that are not immediately apparent and to also analyze how those networks change over time [8]." These tools can be developed even further by looking at the organizational make-up of collective movements and reconciling that perspective with the motivations and hence incentive structures of criminal groups, as well as their means in terms of holding the monopoly of power or sharing the criminal "market" as a cartel. This sub-section is dedicated to expanding the variables investigated so far. 2.1 will briefly outline variable variety; 2.2 will demonstrate how the different variables can be used to trace conditions for infiltration success.

\section{1) Organizational make-up, motivation, and means}

Collective movements exhibit a particular organizational design, hold collective means, and share a collective motivation. In the following, each of these three variables will be described in more detail.

\section{a) Organizational make-up}

The organization of criminal groups can take on multiple, distinct shapes. From mafia groups organized hierarchically over heterarchical drug cartels to loose criminal networks, clandestine movements frequently exhibit innovative capacities in adapting their organizational structures to be effective, successful in their recruitment, and able to undermine counter-measures by preventing detection or infiltration by law enforcement. Different organizational designs come along with different capabilities to innovate. The hierarchically-organized Sicilian mafia, for example, is said to have rarely changed over the decades: "... the organisation has changed little in a century and a half. It emerged, as it remains, in the areas where Sicily's wealth was concentrated, squeezing profitable businesses through its protection rackets [9]." Networks, in turn, are known to be more capable of exhibiting innovation. In fact, Michael Kenney argues that criminal networks learn better from their mistakes than law enforcement agencies: “...criminal networks have a greater need to survive than law enforcement agencies need to apprehend them and thus the criminal networks are more skilled at learning from their mistakes [10]." Clearly, whether a criminal group is hierarchically structured or functions as a network plays out on its innovation capacities. The organizational design of a collective actor is henceforth consequential: "the conceptualization of an actor as a network makes a huge difference in terms of assessing [...] operational and organizational capacity, as well as in terms of ascribing accountability, as opposed to framing this actor as a singular and discrete entity [11]."

\section{b) Means}

Criminal groups not only exhibit variety in terms of their organizational make-up, but also differ in the means at their disposal. The means of a criminal group are dependent on its relationship to other groups competing in the same criminal market. As Adam Dolnik notes referring to terrorist groups, competition is most likely for groups who compete for the same followers: "the closer the ideologies and aims of a given number of groups in the same operational theatre, the greater the need on the part of these groups to differentiate themselves from one another in order to gain a monopoly on the 'dream' that these groups all claim to strive for [12: 161]." The same applies to criminal groups who compete for obtaining the monopoly over the criminal market. Sometimes clandestine groups hold the monopoly of power, sometimes several clandestine groups act as a cartel, and sometimes fierce competition among them escalates fragmentation dynamics. The Mexican drug wars constitute a case par excellence. After the demise of the Colombian Cali and Medellin cartels, Mexican drug cartels have become more powerful. Yet, with the arrest of cartel leaders, a fight for control over the trafficking routes into the US emerged between the different cartels [13]. Similar to the above described dimension of organizational make-up, the means of a criminal group are determined by relationships among actors. However, the focus here lies on the relationship between different collective actors, rather than "hot people."

\section{c) Motivation}

Whereas criminal groups are often defined a priori as apolitical and purely greedy in nature, some movements exhibit political aspirations. Frequently, criminal groups co-opt state structures. The undermining of elections by Mexican drug traffickers constitutes a recent example. In this case, dozens of candidates terminated their races because they faced threats from drug-trafficking cartels [14]. It remains unclear, however, whether such groups have decisively turned political or whether their political ambitions merely function as the means to the end of criminal money-making activities. The co-optation of political structures often serves to stabilize the status quo that facilitates the profiteering of criminal actors. The Sicilian 
mafia figures as a case in point: "The world has changed but the Sicilian mafia has merely adapted; it is today what it has been since it was born: a sworn secret society that pursues power and money by cultivating the art of killing people and getting away with it [15]."

Fig. 1 illustrates how social network analysis can be expanded by increasing the variety of variables:
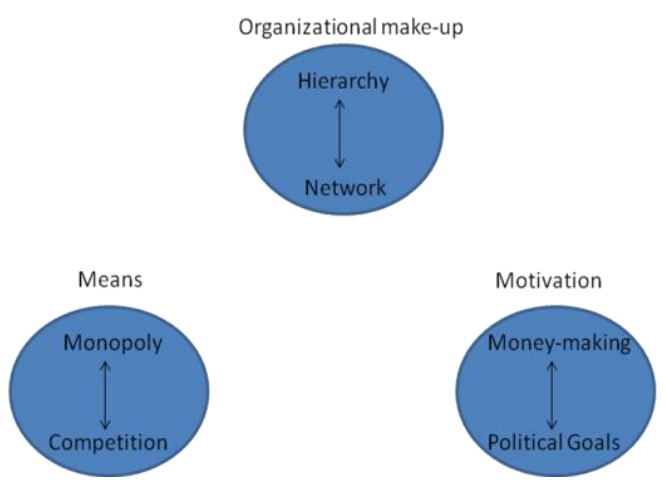

Fig. 1. Variety of variables.

\section{2) Who, when, and what? conditions for infiltration success}

Covert surveillance has played an increasingly dominant role in policing throughout the last century. Especially after September 11, undercover policing has become an important tool for law enforcement in Europe and the United States [16]. The reasons for the development from coercion to deception in criminal investigations are multiple:

"There are a number of reasons behind this shift. In terms of priorities, intelligence-led strategies have been given increased attention within law enforcement agencies, particularly in relation to the investigation of serious drug offences and organized crime. As a consequence, activities traditionally spurned by police as inconsistent with their preventive mandate, such as using an agent provocateur, are now considered fair game [17]."

In order to map out parameters of what is nowadays considered as fair game, (even though undercover operations can still lead to unintended consequences [18], [19]), it is helpful to draw on insights from political science. Supplementing existing research within the field of criminal justice with the conceptual tool box of political science and terrorism research helps to foster increased variable variety as described above. Qualitative analysis of organizational make-up, means, and motivations helps to answer three questions: who to target as a potential informant within clandestine groups, when to seek informants, and what to offer an informant. This qualitative analysis is facilitated through case comparisons. Investigating two extremes, i.e., ideal types, on the respective spectra of the three variables and their implications for infiltration strategies helps to trace the conditions of infiltration success. How the three variables can be coupled with the three questions is outlined below.

\section{a) Who}

In order to answer the first question, the organizational structures of criminal groups can be compared, with a goal of distinguishing the implications of hierarchical versus loosely networked groups for whom to target as an informant. The position of an informant within a clandestine group, determined by the group's organizational make-up, will be decisive for the information he can provide, as well as determine the effect of the information provided. For example, the Albanian mafia is very hierarchically structured. Loyalty, honor, and blood relations play an important role and make infiltration very difficult: "They're like the old Sicilians... They don't roll, and they don't cooperate [20]."

b) When

To address the second question, the means in terms of monopolizing power of criminal groups can be compared in order to distinguish the implications of consolidation versus fragmentation phases for when to seek informants. Whether a clandestine group holds the monopoly of power, whether several clandestine groups act as a cartel, or whether fierce competition among them escalates fragmentation dynamics will determine the benefits as well as risks of infiltration. Thus, "the atomization and combustion that is now so characteristic of Mexico's underworld [21]," does not imply a decrease in violence, but quite to the contrary complicates the dynamics of violence, as well as the options for and efficiency of infiltration. Clearly, the maturity of the criminal market and its different phases determine the means available to criminal groups. A second case comparison could therefore look at the implications of the timing of infiltration for its efficiency in terms of information obtained, as well as in terms of impact on the clandestine groups.

c) What

In answering the third question, the incentive structures of criminal groups can be compared for the purpose of determining what to offer in exchange for information. Whether a clandestine group provides mainly collective incentives such as political reforms, minority rights, or other changes that are beyond calculations of individual gain to guarantee and attract followers, or whether a group limits its incentive structure to selective benefits that only accrue to the individual, such as money or power status, influences what will be an attractive reward in exchange for information. The provision of selective or collective incentives might also play a role in the moral situation in which the informant finds him or herself in [22]. Moreover, what is being offered to attract informants has repercussions on the clandestine group in question. Ascribing a purely greedy nature to criminal groups such as Mexican drug cartels might often be overly simplistic: “...understanding Mexico's drug violence means understanding how [participating] men... see their behavior as following an acceptable moral code, a code which espouses values (machismo, independence, achievement) which would not be out of place in industries besides the drug trade [22]."

Investigating organizational make-up, means, and motivation helps to answer who, when, and what to offer (as information benefits).

\section{B. Making Predictive Policing Dynamic: The Feedback Loop of Infiltration}

Whereas the proposed conceptual design is structured along the lines of three actor components - organization, means, and motivation in order to answer when, who, and 
what to offer (as) information benefits - case comparisons would follow a two-fold direction: elaborating on the implications of actor components for the information obtained and the implications of infiltration strategies for the actor components. This feedback loop will help to outline the adaptation dynamics of clandestine groups to infiltration attempts while simultaneously keeping the focus on maximizing infiltration success. Thus, the feedback loop entails answering what happens if infiltration takes place, and how to infiltrate. Whereas answering what if questions equals a forward projection that leaves the outcome of an intervention open, how to questions project backward, leaving the mode of intervention open in order to reach a set goal. The two different points of departure of this bi-directional approach facilitate investigating infiltration as cause and effect by coupling it with the transformation of criminal groups.

1) How to? The effects of the transformation of criminal groups on infiltration

Infiltration unleashes a dynamic of transformation of the infiltrated criminal group that impacts infiltration itself. Arguably, infiltration constitutes a sui generis method of criminal investigation: "Compared to other methods of criminal investigation, undercover operations are different not only because of their covert and deceptive nature, but also because the police participate in the very crimes they are investigating... [23]" Hence, the transformation of criminal groups clearly has repercussions on infiltration. This first subsection sets infiltration as the effect; in other words, the implications of the transformation of criminal groups on infiltration will be elaborated. This elaboration follows the three-fold structure suggested above, outlining the effects of organizational design, motivation, and means of criminal groups on who, when, and what to offer as information benefits.

\section{a) Organizational make-up}

The organizational make-up of a criminal group is decisive for whom to spot as a possible informant, because different entry points have different implications for infiltration. In more hierarchically organized groups, infiltrating might be more difficult the more the infiltrator approaches the top level, and as loyalty bounds and responsibilities increase. Moreover, it might be crucial to consider infiltrating at the mid-range, because informants in the middle often reach out in both directions: top and down. Stefan Mair has observed that transnational criminal organizations (TCOs) increasingly work as networks in small cells cooperating with each other while specializing functionally: "Colombians cartels/gangs focused on cocaine; Afghans on heroin; Nigerians, Turkish, Kurdish, Albanians and Russian groups as middlemen in drugs and human trafficking, etc. TCOs also act as middlemen or facilitators for terrorists, warlords and rebels in insurgencies [24], [25]" Infiltrating at the mid-range should thus be especially promising in yielding information. The information obtained from infiltrating the mid-range will thereby differ depending on the (de-)centralization of the groups. In more decentralized networks, infiltrating and placing informants at nodes might be less informative than information obtained when infiltrating more hierarchically-organized groups, because networks often serve to control information flows and limit the consequences of potential infiltration attempts.

\section{b) Means}

The means of a criminal group in terms of its (shared) monopoly of power have implications on when to seek informants. Criminal collective actors go through phases of fragmentation and consolidation. In might be easier to infiltrate in periods of fragmentation than in periods of consolidation, as the infiltrators can benefit from divided groups by playing actors against each other. At the same time, infiltrating consolidating or consolidated groups might result in obtaining more meaningful information. Moreover, infiltrating fragmenting groups can yield increased risks for the infiltrators. While fragmentation sometimes helps to reduce violence, it can also lead to increased levels of violence. Comparing the experiences of Colombia and Mexico is striking in this regard:

"One of the heralded lessons of Colombia's fight against drug cartels is that fragmentation reduces violence.... A U.S. law enforcement official once told me that their antidrug strategy in Mexico was first to go after the wolves (the highest level cartel leaders), then go after the snakes (the next level down), and then clean up the remaining rats... But as the Mexican cartels multiplied, violence escalated to all time highs [26]."

\section{c) Motivation}

Whether group members are motivated purely by greed or also exhibit political ambitions is decisive for what to offer an informant as an information benefit. The incentive structures of collective criminal movements are crucial in determining how to bait potential informants. Even if criminal groups co-opt state structures in order to stabilize a status quo that permits their continuous profiting rather than striving for political change, political ambitions can make a difference on the information obtained as a result of different information benefits.

As Fig. 2 illustrates, projecting backward helps to answer how to infiltrate criminal groups:

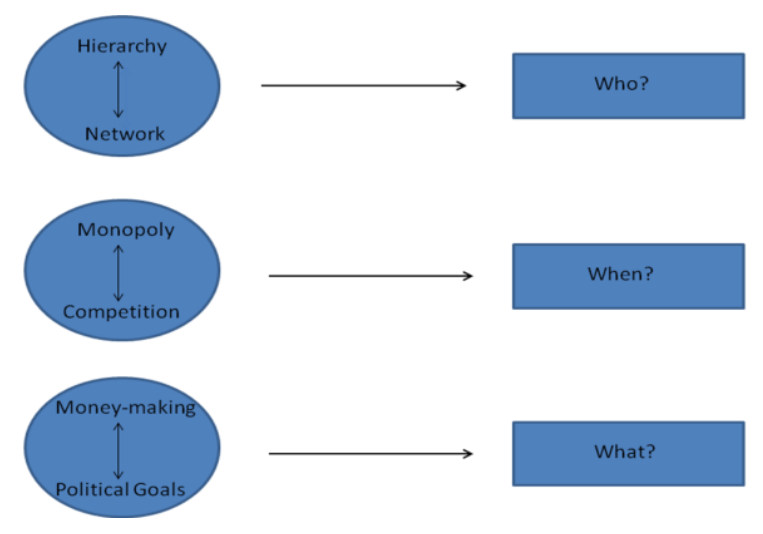

Fig. 2. Projecting Backward.

\section{2) What if? The effects of infiltration on the transformation of criminal groups}

Often, members of clandestine groups are able to spot infiltrating undercover agents. Building on interviews with 
heroin users and dealers, Bruce Jacobs suggests two types of undercover deception clues, trend discontinuity and interpersonal illegitimacy:

"Trend discontinuity is associated with police informants and results from situations in which (I) familiar customers suddenly introduce unfamiliar others who wish to buy drugs and (2) familiar customers suddenly and significantly increase quantities they themselves desire to purchase. Interpersonal illegitimacy is associated with undercover agents and results from situations in which unfamiliar buyers emit certain physical and verbal "vibes" believed to be indicative of covert law enforcement personnel [27].",

These deception clues help members of criminal groups to spot undercover agents. In Cosa Nostra: A History of the Sicilian Mafia, John Dickie elaborates on the confessions of mafia boss Tommaso Buscetta to investigator Giovanni Falcone, among others, on the mafia concept of honor. In line with this concept, men of honor must tell one another the truth. In practice they therefore avoid saying anything directly at all: "The interpretation of signs, gestures, messages and silences is one of a man of honour's main activities [28]." Being trained to interpret signals helps men of honor to detect diverging behavior. When clandestine groups detect undercover agents, they are pushed to adapt their modus operandi: "Hypothetically, informants extend the reach and perceived presence of law enforcement through redirection of criminal attention to the constant possibility of undercover infiltration [29]." Not only does the transformation of criminal groups impact infiltration strategies, infiltration strategies also impact the transformation of criminal groups. Arguably, "[a]mong investigative tactics, undercover policing is unique in the extent to which it allows the police to shape the events they investigate [30]." Whereas the previous subsection addressing how to questions entailed a backward projection, asking what if questions projects forward, leaving the outcome of intervention strategies open. Accordingly, this subsection sets infiltration as the cause in order to investigate its effects on the transformation of criminal groups. It proceeds by following the three-fold structure of organizational make up, means, and motivation.

\section{a) Who}

Infiltrating clandestine groups can have diverse effects on their transformation. Who is targeted as an informant is thereby consequential. If a criminal group is organized in a rather hierarchical manner, infiltrating at a high level frequently comes along with the leadership's loss of legitimacy. If a criminal collective actor is bound together in shape of a loose network, a loss of trust that served to substitute for the lack of leadership and hold together otherwise disparate actors can occur. Furthermore, if criminal groups do not respect hierarchies, going after the "heads" will be inefficient:

"If the violence isn't ordered from on high..., then taking out the top echelons of the cartels won't end it. Furthermore, if most of the bloodshed is between the criminals themselves, going after the heads will just escalate the cycle, as more and more mid-level criminals fight it out for control of the remaining business... [31]”,

\section{b) When}

Whether a criminal group or several competing criminal groups go through phases of fragmentation or consolidation is consequential for infiltration strategies in terms of when to choose an informant in order to maximize the benefit of information obtained. Simultaneously, the timing of choosing an informant can be consequential for the criminal group in question. Infiltration can thus lead to further fragmentation of the group(s), especially if it is successful. As a case in point, American law enforcement agencies have built up a network of informants in Mexico allowing them to infiltrate the country's drug cartels with the result of the cartel's further fragmentation: "[t]he efforts have been credited with breaking up several of Mexico's largest cartels into smaller - and presumably less dangerous - crime groups [32], [33]" On the other hand and quite to the contrary, failed infiltration attempts can increase the consolidation of criminal groups whose members flock together to protect themselves against infiltration.

c) What

Infiltration has different implications for collective actors whose members are motivated purely by greed than for those groups whose members also share political ambitions. If a criminal group exhibits political goals, for example, as a result of merging with a terrorist group, infiltration and the loss of legitimacy that comes along with it can negatively affect its recruitment abilities. (As an example of the dissolution of an illegal group with political ambitions as a result of benefits given in return for cooperation with the judicial system, the pentiti in Italy seriously impacted upon the Red Brigades as well as upon Italian Mafia organizations [34].) Infiltrating criminal groups motivated purely by making money, in turn, might either result in a loss of trust and members' defection from the group, or can - on the opposite end - lead a group to develop political ambitions. Thus, criminal groups can come to see the benefits of co-opting state structures in order to be more influential and fend off infiltration attempts. At the same time, however, groups initially formed to pursue political aims can also degenerate into criminal gangs. The Colombian guerrilla is often cited in this context: "Initially committed to the overthrow of the Colombian government, the Revolutionary Armed Forces of Colombia (FARC) evolved into a commercialist insurgency focused on controlling the Colombian countryside for the purpose of drug cultivation [35]."

As Fig. 3 illustrates, projecting forward helps to answer what if there is infiltration:

\section{Synthesizing Concepts}

Intelligence software systems can be expanded by increasing variable variety from focusing purely on organizational design to including motivation and means. It can furthermore be made dynamic by including the impact of and on interventions such as infiltration strategies. It becomes still more complex and reflective of reality if the variables are interrelated and infiltration dynamics are connected to variable interrelation. Thus, the transformation 
of organizational make-up, means, and motivation often comes together such that a change in one variable impacts the change of another variable. Furthermore, this interrelation can be connected to infiltration.

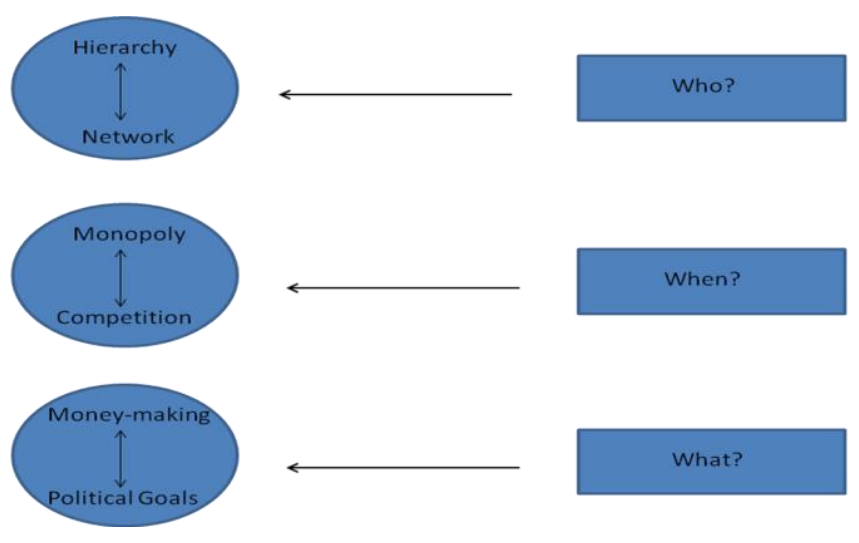

Fig. 3. Projecting forward.

1) Interrelating variables: The connection between organizational make-up, motivation, and means

This first subsection of Section IV will outline how the transformation of one variable often comes in connection with the transformation of another one. It follows a three-fold structure by elaborating on the three variable dyads:

a) Organizational make-up and means

The organizational design of a criminal group influences its means. Both hierarchically-structured groups as well as loose networks exhibit advantages and disadvantages when it comes to taking over and sustaining a monopoly of power. Thus, clear command structures can facilitate control of members and the market, whereas networked groups are more flexible in adapting to changing means. The adaptation capabilities of criminal groups have implications for governmental counter-measures. Sometimes, coercive initiatives can make problems worse, as argued by Cornelius Friesendorf: "By constructing a perception of drugs as a national security issue and by starting a "war on drugs," US policy makers adopted coercive, oversimplified strategies against complex problems [36]."

\section{b) Organizational make-up and motivation}

The organizational design of a criminal group also has an impact upon the motivation of its members. Chris Dishman, for example, posits that a leaderless nexus emerges between criminal and terrorist groups that leads to the criminalization of the groups' members:

"The rise of networked organizations has given greater independence to criminals and terrorists who previously answered to a clear chain of command. These members are now willing to engage in operations that before had been off-limits because the leadership believed the activity would hurt the organization's broader mandate. ... Because members join to make money, they will quickly set ideological goals to the side if it affects profits [37]."

\section{c) Means and motivation}

Whether criminal groups hold the monopoly of power over the crime market and are in a phase of consolidation, or whether they fragment and compete with other criminal groups in the crime market, has an effect upon the groups' motivation. Thus, the criminal actor's ability to co-opt state structures is influenced by its share of the criminal market i.e., its means. Fragmenting groups usually have less means to coordinate at their disposal and thus are less capable of infiltrating the state. Simultaneously, the motivation of criminal groups also influences the implications of their fragmentation or consolidation. Shannon O'Neil explains that the fragmentation of the Colombian drug cartels came along with a decrease in violence, whereas the fragmentation of Mexican drug cartels was accompanied by an increase of violence because of their different relations vis-à-vis the state:

"...the killing first of Pablo Escobar and then the arrest and conviction of the Rodríguez Orejuela brothers fragmented the cartels and their command structures. [...] In Mexico, by contrast, the cartels are not openly and directly confronting the state. Sure, they threaten, co-opt and even increasingly kill local and state police and elected representatives. But their open letters -narcomantas hung over important intersections - are primarily directed to their drug trafficking rivals, or to local political alignments."

Organizational make-up, means, and motivation are thus highly interrelated, as Fig. 4 illustrates:

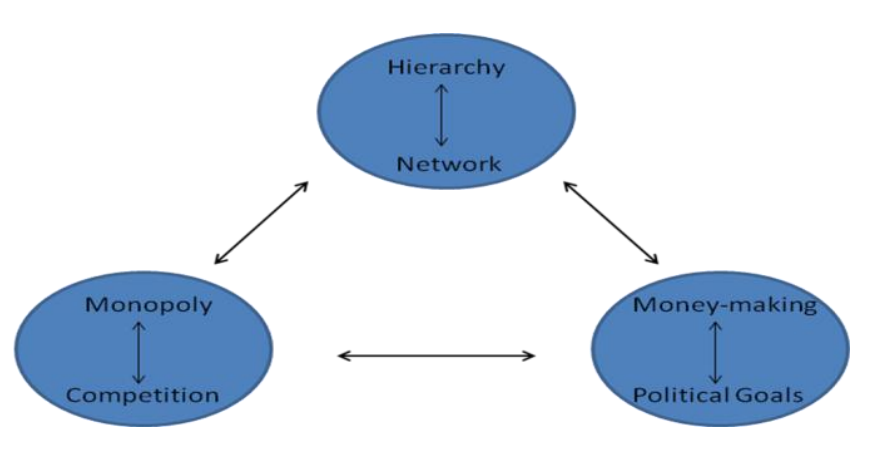

Fig. 4. Variable interrelation.

\section{2) Connecting variable interrelation and infiltration dynamics}

Finally, variable interrelation and infiltration dynamics are connected. The interrelation of the transformation of organizational make-up, means, and motivation is affected by and affects infiltration. In the following subsections, this complexity will be depicted by combining infiltration strategies and variable interrelation.

a) Who and when to offer information benefits and the interrelation between organizational design and means

Who is targeted as an informant - upper or lower-bottom or middle-range - has not only implications for organizational design, but is also closely related to the ability of the criminal group to obtain and maintain a monopoly of power. Hierarchies tend to have more control; networks are more flexible. If a loss of legitimacy occurs as a consequence of infiltration within a hierarchically-organized criminal group, fragmentation can increase. This is the case because members might start joining other groups that compete in the same criminal market. Networks, on the other hand, might be 
more flexible and able to adapt to infiltration. Criminal groups frequently act in networks in order to render infiltration useless. Thus, members of the network have enough much information so that they can operate but not so much that they can destabilize other cells of the network by giving in to infiltration attempts. Therefore, the network's monopoly of power might be less threatened than in the case of infiltrated hierarchies. However, hierarchical groups can turn into networks as a consequence of infiltration attempts and hence undergo a transformation of their means as well.

b) Who and what to offer (as) information benefits and the interrelation between organizational design and motivation

Interestingly, ideologization and criminalization can go hand in hand. This puzzling development, observable for example in groups such as Al Qaeda in the Islamic Maghreb, demands explanation. In order to provide an answer, it is useful to study the implications of the crime-terror nexus for the organizational make-ups of previously purely ideological or criminal groups and the consequences thereof for infiltration success. Hierarchical terrorist groups are more easily influenced by infiltration. Especially when undercover agents manage to infiltrate the group at a high level of the hierarchy, the group risks losing legitimacy and thus becomes less attractive for recruits. Cooperation with criminal groups, as well as the transformation into network structures, implies that the demands for legitimacy and hence the risk of losing legitimacy when being infiltrated is decreased, because no one who would assume responsibility can be pin-pointed. Additionally, terrorist groups can now benefit from recruiting members that are motivated by either criminal or ideological factors. Criminal groups, on the other hand, which frequently function as networks and which depend on trust within that network, benefit from cooperation with ideologically motivated groups in that the tendency to defect, and hence the risk of infiltration succeeding in the first place, is diminished, because ideology becomes the additional glue for otherwise disparate actors. Simultaneous ideologization and criminalization therefore make infiltration less effective as well as less likely.

c) When and what to offer (as) information benefits and the interrelation between means and motivation

When informants are targeted and what is offered as information benefits impacts not only the transformation of means and motivation, but also the interrelation between both processes of change. Criminal groups that go through phases of fragmentation as a result of infiltration might adapt their incentive structures in order to counter-balance the potential loss of recruits. At the same time, fragmenting groups face harder times regarding attempts to co-opt legal structures confining their political ambitions. Groups that (further) consolidate as a result of infiltration face the opportunity of developing and realizing political ambitions as their monopoly of power over the criminal market will help to be the only one co-opting state structures. At the same time, however, competition between criminal actors and the fragmented criminal market that results from this can also imply that the state is decisively weakened, and that state structures are therefore easier to co-opt. What is offered as information benefits, in turn, not only impacts the motivation of criminal groups but can also affect their means - both as a result of what is offered as well as a consequent change in a criminal group's motivations. Members who are baited with political incentives, i.e., cooptation of state structures, might reveal crucial information that can lead to the fragmentation of the criminal market in terms of increasing competition among groups. By connecting variable interrelation and infiltration dynamics, a complex picture of feedback loops can be drawn as Fig. 5 illustrates:

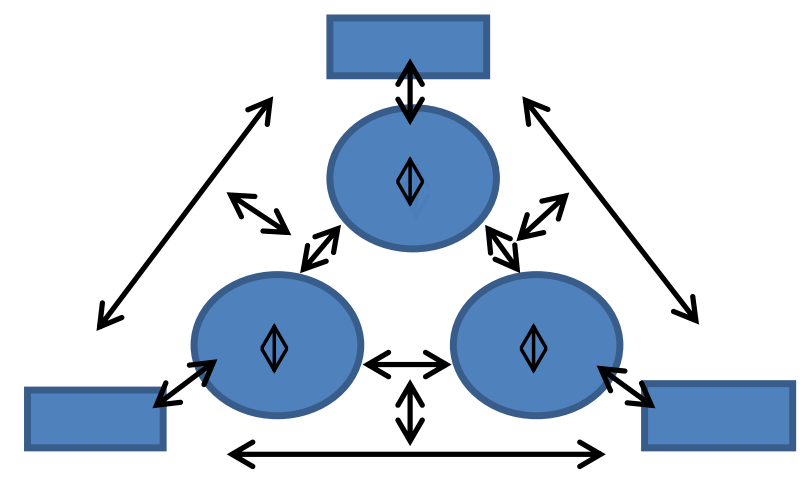

Fig. 5. Complexity of feedback loops.

\section{Summary}

Predictive policing offers a sophisticated tool to enable predictions about criminal activity. Clearly, collecting data on organized crime constitutes a feat: "[i]t is, of course, almost impossible to gather reliable information on organized crime: the Mafia does not publish company reports [38]." The lack of reliable information speaks in favor of increasing factor variety and hence improving predictive policing. This paper added a further possibility for improving predictive capability: qualitative research. Besides suggesting that predictive policing be broadened by including a qualitative methodological approach, the paper also advocated an expansion of the variables taken into account, as well as including not only organizational design but also motivation and means in the analysis. Finally, the paper sought to make predictive policing dynamic by considering addressing "hot interventions" of "hot collective movements." Whereas this conceptual tool can be seen as a supplement to quantitative analysis, both qualitative and quantitative data can also be combined to draw an even more accurate model that comes closer to reality and improves chances of successful prediction. Social network analysis "is an analytical tool in the intelligence analysis toolbox, not a "silver bullet." It merely provides users with a starting point for areas that warrant further analysis [8]." Taking advantage of methodological pluralism can potentially serve to make predictive policing even more predictive.

\section{REFERENCES}

[1] W. Perry, B. McInnis, and C. C. Prize, "Predictive policing the role of crime forecasting in law enforcement operations," Santa Monica: Rand Corporation, September 2013.

[2] R. Archibold. (October 7, 2010). Mexican leader pushes police overhaul. The New York Times. [Online]. Available: http://www.nytimes.com/2010/10/08/world/americas/08mexico.html? r $=0$ 
[3] E. Joh, "Breaking the law to enforce it: Undercover police participation in crime," Stanford Law Review, vol. 62, pp. 155-196, December 2009

[4] M. Amir, "Criminal Undercover Agents or 'Bad People' doing 'Good Things," Substance Use and Misuse, vol. 38, no. 10, pp. 1425-1431, 1995.

[5] G. T. Marx, Undercover: Police Surveillance in America, Berkeley and Los Angeles: University of California Press, 1989.

[6] C. Fijnaut and G. T. Marx, The Normalization of Undercover Policing in the West: Historical and Contemporary Perspectives, Police Surveillance in Comparative Perspective, The Hague: Kluwer Law International.

[7] G. Miller, "Observations on police undercover work," Criminology, vol. 25 , no. 1 , pp. 27-46, 1987.

[8] Social Network Analysis, Analyst's Notebook 8, no. 3, June 2010.

[9] C. Longrigg. (February 20, 2004). Review of Cosa Nostra: A History of the Sicilian Mafia by John Dickie. The Guardian. [Online]. Available: http://www.theguardian.com/books/2004/feb/21/featuresreviews.guar dianreview3

[10] S. Davies, "Review of from pablo to osama: trafficking and terrorist networks, government bureaucracies and competitive adaptation by michael kenney," International Affairs, vol. 83, pp. 975-1011, September 2007.

[11] G. Kolliarakis, "Networks and the study of Criminal and Terrorist Organizations," in Transnational Terrorism, Organized Crime, and Peace-Building, W. Benedek, C. Daase, V. Dimitrijevic, and P. van Duyne, Eds., London: Palgrave Macmillan, 2010, pp. 81-97.

[12] A. Dolnik, Understanding Terrorist Innovation: Technology, Tactics and Global Trends, Abingdon: Routledge, 2007.

[13] M. Sullivan, "CRS report for congress, Mexico-US relations: Issues for congress," Congressional Research Service, September 2, 2011.

[14] T. Wilkinson. (November 14, 2011). Mexican Drug Traffickers Undermine Elections. [Online]. Available: http://articles.latimes.com/2011/nov/14/world/la-fg-mexico-michoaca n-elections-20111114

[15] J. Dickie, Cosa Nostra: A History of the Sicilian Mafia, New York: Routledge, 2007.

[16] J. Ross, "The place of covert surveillance in democratic societies: A comparative study of the united states and germany," The American Journal of Comparative Law, vol. 55, no. 3, pp. 493-579, 2007.

[17] S. Bronitt, "The law in undercover policing," Common Law World Review, vol. 35, pp. 35-80, 2004

[18] J. Wachtel, "From morals to practice: dilemmas of control in undercover policing," Crime, Law and Social Change, vol. 18, 1992, pp. $137-158$.

[19] S. Levinson, "Under cover: the hidden costs of infiltration," The Hastings Center Report, vol. 12, no. 4, pp. 29-37, 1982.

[20] K. Fahim. (January 3, 2006). Beating them at their own game. The New York Times. [Online]. Available: http://www.nytimes.com/2006/01/03/nyregion/03albanian.html

[21] E. Pachico. (August 23, 2011). Mexico Cartel Gunman Discusses Brutal Killings. InSight. [Online]. Available: http://www.insightcrime.org/news-analysis/mexico-cartel-gunman-dis cusses-brutal-killings

[22] C. Harfield, "Police informers and professional ethics," Criminal Justice Ethics, vol. 31, 2, pp. 73-95, August 2012.

[23] J. E. Ross, "Undercover policing and the shifting terms of scholarly debate: The united states and Europe in counterpoint," Annual Review of Law and Social Science, vol. 4, pp. 239-273, December 2008.

[24] S. Mair, "The new world of privatized violence," Internationale Politik und Gesellschaft, 2, 2003.

[25] R. Bunker, Networks, Terrorism and Global Insurgency, Abingdon: Routledge, 2005.

[26] S. K. O'Neil. (August 9, 2011). Drug Cartel Fragmentation and Violence. Council on Foreign Relations Blog. [Online]. Available: http://blogs.cfr.org/oneil/2011/08/09/drug-cartel-fragmentation-and-vi olence/

[27] B. Jacobs, "Undercover deception clues: A case of restrictive deterrence," Criminology, vol. 31, no. 2, pp. 281-299, 1993.
[28] C. Longrigg. (February 20, 2004). Review of Cosa Nostra: A History of the Sicilian Mafia. The Guardian. [Online]. Available: http://www.theguardian.com/books/2004/feb/21/featuresreviews.guar dianreview3

[29] J. M. Miller, "Becoming an informant," Justice Quarterly, vol. 82, no. 2, pp. 203-220, September 2010.

[30] J. E. Ross, "Undercover policing and the shifting terms of the scholarly debate: The united states and Europe in counterpoint," Annual Review of Law and Social Science, vol. 4, pp. 239-273, December 2008.

[31] S. K. O'Neil. (August 9, 2011). Drug Cartel Fragmentation and Violence. Council on Foreign Relations blog. [Online]. Available: http://blogs.cfr.org/oneil/2011/08/09/drug-cartel-fragmentation-and-vi olence/

[32] G. Thompson. (October 24, 2011). Agencies Infiltrating Drug Cartels Across Mexico. [Online]. Available: http://www.nytimes.com/2011/10/25/world/americas/united-states-inf iltrating-criminal-groups-across-mexico.html?pagewanted=all

[33] L. Paoli, Mafia Brotherhoods: Organized Crime, Italian Style, Oxford: Oxford University Press, 2003

[34] P. J. P. Tak, "Deals with criminals: Supergrasses, crown witnesses and pentiti," European Journal of Crime, Criminal Law and Criminal Justice, vol. 5, no. 1, pp. 2-26, 1997.

[35] L. Kiran, (2010). A Different Fight: Narco-Commercialist Insurgencies in Mexico, [Online]. Available: http://www.wm.edu/offices/itpir/_documents/pips/2009-2010/policy_ briefs 2010.pdf

[36] C. Friesendorf, US Foreign Policy and the War on Drugs, Abingdon: Routledge, 2007.

[37] C. Dishman, "The leaderless nexus: When crime and terror converge," Studies in Conflict and Terrorism, vol. 28, pp. 237-252, 2005.

[38] S. Mair, "The new world of privatized violence," Internationale Politik und Gesellschaft, vol. 2, 2003.

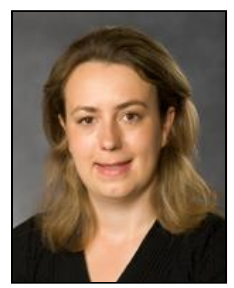

Carolin Goerzig was born in Greifswald, Germany in 1979. She received her bachelor of international relations from the Technical University of Dresden, Germany in 2002, She received her master degree of international conflict analysis from Kent University, BSIS, Belgium in 2004. She received her doctoral degree in political science from the University of Munich, Germany, 2009

She is currently an assistant professor in the Homeland Security Program of the L. Douglas Wilder School of Government and Public Affairs of Virginia Commonwealth University in Richmond, U.S. She specializes in the role of non-state actors in global politics, with a particular emphasis on non-state armed groups as a challenge to foreign and security policy. Her previous affiliations include a visiting researcher at the London School of Economics, postdoctoral fellowships at the RAND Corporation and the EU Institute for Security Studies, and a pre-doctoral fellowship at the Department for Peace and Conflict Research of Uppsala University. Her current research examines the radicalization of Muslims in Europe and the US, lone-wolf terrorism, terrorist learning, and terrorist cooperation.

Dr. Goerzig is a member of the International Studies Association, of the German woman academics, and of the society of terrorism research. In 2007 Dr. Goerzig received the second young researcher prize for her paper "Predicting Terrorism" at the biennale of negotiations in Paris. Dr. Goerzig's book "Negotiating with Terrorists: Concessions and the Renunciation of Violence" was recognized as the CHOICE Outstanding Academic Title of the Year in 2011. The book as well as two of Dr. Goerzig's book chapters, were listed among the top 150 books on terrorism and counter-terrorism by the journal Perspectives on Terrorism. She recently published her second book (co-authored) "Radicalization in Western Europe." 